\title{
GLADIATORS AT ANCYRA
}

\author{
Julian Bennett ${ }^{1}$
}

\section{INTRODUCTION}

The public fascination with the gladiators of the Roman Empire was exemplified relatively recently by the highly commercial success of the US \$110 million film Gladiator (2000), albeit those from an earlier generation or knowledgeable on the subject matter prefer its more reliable and oft-repeated predecessor, Spartacus (1960). Despite the popularity of these films, and their bias towards the gladiators of Rome and Italy, it is surprisingly little known just how ubiquitous gladiatorial displays were in the Roman World. This is especially true of its Hellenised parts, areas where earlier historians believed the local 'civilised' peoples rejected such 'barbaric' spectacles on high moral grounds. ${ }^{2}$

It is a fact that purpose-built permanent amphitheatres are rare in the Greekspeaking parts of the Roman Empire. In Anatolia, for example, only three are known, at Anazarbus, Pergamum, and Cyzicus, although the double-ended stadium at Laodicea (dedicated between AD 79 and 81) was clearly designed for gladiatorial shows also, as its

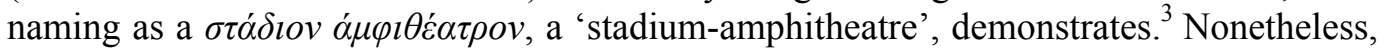
convincing evidence for the popularity of such shows in this specific region is provided by the physical remains of theatres converted for the purpose at a number of Anatolian poleis: at Ephesus, for example, a $2.5 \mathrm{~m}$. high screen wall replaced the lower rows of seats around the orchestra to protect spectators from escaping animals or gladiators. ${ }^{4}$ Even better, the same polis has revealed graphic evidence for the way in which gladiatorial fights were often to the death. Forensic analysis of 67 male skeletons from the Ephesus 'gladiator's cemetery' has revealed explicit evidence for the violent manner in which

\footnotetext{
${ }^{1}$ Department of Archaeology and Art History, Bilkent University, Ankara: bennett@bilkent.edu.tr. I am greatly indebted to the students of my 2008 Hellenistic and Early Roman Anatolia course at Bilkent for prompting this paper. I also thank my colleagues J. Morin, who provided his usual invaluable assistance with the relevant texts (but who is naturally not responsible for my interpretation of these); and Ben Claasz Coockson for the drawings.

${ }^{2}$ The belief was based on the writings of those belonging to the Second Sophistic, e.g., Plut. Non Posse 1099b, referring to gladiators 'who are not altogether bestial' - albeit in the sense they were on a higher moral plateau to the lowest of the low, the Epicureans. Perusal of the seminal studies by Robert 1940, 1946, 1948, 1949 and 1950, with over 340 gladiatorial texts and reliefs from the Greek-speaking world, should dispel completely any doubts on their popularity in the Romanised Hellenic World.

${ }^{3}$ For Anazarbus, at about 62 × 83 m. internally, cf. Gough 1952, 100; for Pergamum, at about $180 \times 150 \mathrm{~m}$. externally, cf. Radt 1999, 263-66; for Cyzicus, also at about 180 x 150 m. externally, cf. Rustafjaell 1902, 186-87, with Hasluck and Anderson 1904, 140-41. For Laodicea, cf. Welch 1998a, 563, and especially IGR 4.845 and 861: other doubleended stadia such as that at Aphrodisias and Nicopolis were also presumably designed with this purpose in mind: Welch 1998a, 559-561 and 563-565.

${ }^{4}$ The best-documented example of the process is at Corinth: cf. Stillwell 1952, 84-98.
} 
some of them died, mainly through cranial injuries, the result of the 'death-blow' inflicted on mortally wounded gladiators. ${ }^{5}$ Moreover, Ephesus can also claim a place of fame - if that is the right word - in being the first Anatolian polis known to have held any form of gladiatorial display, L. Licinius Lucullus holding a gladiatorial show there in 70/69 BC to commemorate his victory over Mithridates and the restoration of law and order to greater Anatolia. ${ }^{6}$ That aside, perhaps the most persuasive evidence for the popularity of shows of this nature throughout Anatolia is to be found in the form of the many funerary monuments of deceased gladiators reported from the major urbanised centres of Asia Minor. Ancyra, the metropolis of Galatia, has its own fair share of such monuments, along with other reliefs and epigraphic texts relating to the various gladiatorial games held there, and it is these that provide the main focus of this paper. Before looking at the evidence from Ancyra, however, it may be useful to briefly review the evidence for the gladiatorial games in their wider context. ${ }^{7}$

\section{THE GLADiATORIAL GAMES}

Despite some uncertainty over their precise origin, the Romans certainly adopted the idea of gladiatorial shows as a form of public spectacle from the Etruscans, the first such 'spectacle' at Rome being held in 264 BC as part of the funeral ceremonies for D. Junius Brutus. ${ }^{8}$ This was offered as a munus, a 'duty' paid by his sons as a way of keeping his memory alive, and funeral munera of this kind were held until the final days of the Republic. But when Julius Caesar promised to pay for 320 gladiatorial matches at the funeral games of his daughter Julia in $46 \mathrm{BC}$, his ostensibly altruistic motives were recognised for what they really were: electoral bribery. In fact by then, gladiatorial shows whether for entertainment and/or as a covert or even overt electoral bribe had certainly become a part of the way of life in some parts of Italy, as is shown by the construction at Pompeii of the earliest known purpose-built amphitheatre in $c .80 \mathrm{BC}$.

The political and electoral value of the munera promoted by those seeking or elected to public office was one of the many matters Augustus thought necessary to regulate during his reforms to the earlier Republican system of government at Rome. Thus he placed a limit on both their frequency and expense, ${ }^{9}$ although he happily provided them in his own name whenever he thought necessary or appropriate: indeed, he

\footnotetext{
5 For a general introduction to the evidence, cf. Krinzinger 2002; for more detailed studies of the injuries, cf. Kanz and Großschmidt 2002, 2005 and 2006.

${ }^{6}$ Plut. Luc. 23. For other gladiatorial shows in Asia Minor in the pre-Imperial period, cf. Cic. Att., 6.3.9, referring to gladiators at Laodiceia, and Phil. 6.13, noting a combat between a murmillo and thraex at Mylassa; also Dio 51.7.2-7, reporting gladiators at Cyzicus who belonged to a private school maintained by Mark Antony.

${ }^{7}$ Despite its lack of an index, Junkelmann 2000 provides the most succinct analysis of the origins, history, weapons, armour and techniques of the gladiators and the gladiatorial games. Although there is epigraphic and figural evidence from Ancyra for the venationes or wild-beast hunts that frequently took place in association with gladiatorial games, discussion of these events is excluded from this article, as they involved professional venatores and bestiarii, not gladiators.

${ }^{8}$ Val. Max. 2.4.7.

${ }^{9}$ Dio 54.2.3-4.
} 
paid for no less than eight different games involving some 5,000 pairs of gladiators before his death in AD 14. ${ }^{10}$ Nero, for his part, also faced the problem of gladiatorial shows being used as a form of bribery, in this case by his provincial governors and procurators: thus his decree of AD 58 forbidding them from holding such spectacles on the grounds they were methods of corruption. ${ }^{11}$ However, as before, private citizens were allowed to hold their own munera outside of Rome and the popularity of such shows might be gauged from Nero's decision to punish Pompeii for a riot in its amphitheatre in AD 59 by banning any munera there for a period of 10 years. ${ }^{12}$ That aside, the reign of Trajan saw a peak in gladiatorial games at Rome, with 10,000 displayed over 123 days to celebrate his capture of Dacia, ${ }^{13}$ although the high point for these shows in Anatolia probably came in the mid- $2^{\text {nd }}$ century, to judge from the widespread adaptation of theatres for this purpose at that time. ${ }^{14}$ Moreover, the same general period saw the issue of an imperial fiat to limit the use of public funds for such displays. ${ }^{15}$ As it was, the widespread economic collapse associated with the 'Third Century Crisis' undoubtedly resulted in a forced decline of gladiatorial events, with gladiators (and wild animals) for display purposes being harder to obtain. In any case, by the beginning of the $4^{\text {th }}$ century public attitudes towards gladiatorial shows were changing: thus Constantine seems to have faced little opposition when he issued a decree in 325 banning gladiators from public spectacles, ${ }^{16}$ although they continued to perform into the $5^{\text {th }}$ century. ${ }^{17}$

By the High Empire, it seems that four classes of gladiators had become especially common. Two were of the 'heavy' class, the murmillo, named for the fishfin-like crest on his helmet, and who was armed with a short straight gladius; ${ }^{18}$ and the thraex, named for his 'Thracian'-type sica, a sword 'bent' at an angle of about 30 degrees in the middle to give an upturned point. ${ }^{19}$ Both of these types of gladiator carried large rectangular shields and wore a closed helmet with a network-pierced visor and a flanged neck-guard, the helmet worn by the thraex having a crest terminating in an animal protome. In addition, both types wore fasciae, a thick padded arm protector on their right arms, while the murmillo also wore a single short greave on his left leg, the thraex having a pair of long greaves. The two other common classes of gladiator were of the 'light' variety, namely the secutor, or 'chaser', who was armed with a gladius ${ }^{20}$ and (his usual opponent) the retiarius or 'fisherman', named after the trident, weighted net and dagger that formed his

\footnotetext{
${ }^{10}$ Res Gestae 22.1.

${ }^{11}$ Tac. Ann. 13.31 .

12 Tac. Ann. 14.17.

${ }^{13}$ Dio 68.15; cf. Bennett 2001, 101-102.

${ }^{14}$ Golvin 1988, 237: the theatre at Aphrodisias, for example, was converted under Antoninus Pius (AD 139-61): Reynolds 1991, 19.

${ }^{15}$ Dig. 1.8.6, of Hadrian or Antoninus Pius. Note also a senatorial decree of AD 177 placing a limit on spending for the spectacles: Mitchell 1993, 110, with n. 68 and 70.

${ }^{16}$ Cod. Theod. 13.12.11; cf. Cod. Just. 11.44.

${ }^{17}$ Welch 1998a, 568, with n. 74.

${ }^{18}$ Junkelmann 2000, 110-11.

${ }^{19}$ Junkelmann 2000, 119-20.

${ }^{20}$ Junkelmann 2000, 111.
} 
offensive weapons. ${ }^{21}$ The secutor wore an egg-shaped helmet with a thin upright crest and two eyeholes in the visor, and carried a large rectangular shield, along with fasciae on his right arm and a short greave on his left leg. The retiarius, however, wore neither helmet nor greaves, nor did he carry a shield: his defensive armour consisted solely of fasciae on his left arm, with a short metal manica protecting his left shoulder and extending upwards to cover the left side of his neck.

Generally speaking, a single combat between two gladiators involved a murmillo against a thraex or a secutor against a retiarius, but this rule was not an exclusive one, with other combinations (and other classes of gladiators) being known from the literature and from depictions on mosaics and so forth. That apart, the literary evidence is clear that during the High Empire, many gladiators were 'amateurs', in the sense of being men pressed into such service (damnatus ad ludum), either as prisoners of war, or as condemned criminals worthy of something more than straightforward capital punishment. $^{22}$ However, from both the literary and the epigraphic evidence it is equally clear that many gladiators were true 'professionals', who belonged to private or imperial schools or familiae, either as slaves bought and trained for the purpose, or as freemen who volunteered for the fame and prosperity that came to a highly successful gladiator. Thus while gladiatorial shows between the 'amateurs' were little more than brutal fights to the death until the last man available that day was standing, the 'professionals' fought by rules, with a senior and junior referee, the summa and secunda rudis, supervising combat. ${ }^{23}$

These referees took their titles from the wooden rod (rudis) they carried, and with which they could interrupt a fight whenever necessary. This might be after an agreed time, when one man was declared the winner, but perhaps more usually when one gladiator suffered either from exhaustion or a serious flesh wound, signalling his defeat by raising the fore-finger of his left hand in the air: hence the popular cry that a fight be 'to the finger' and not a timed event. ${ }^{24}$ Less usually, or so it would seem, at least in the early Imperial Period (see below), the fight would be to the death - 'less usually' simply because professional gladiators were expensive investments, and several epigraphic texts testify how some defeated or wounded gladiators certainly did live to fight another day. If, however, the crowd so-desired, a defeated gladiator was condemned to die through their use of the pollice verso, the 'turned thumb'. ${ }^{25}$ Popular belief would have it that this was the 'thumbs-down', but documentary evidence and marks on the throat-vertebrae of certain gladiator skeletons at Ephesus suggests it was the 'thumbs-up', signifying death by an upward thrust with sword or dagger beneath the chin of the man thus condemned. On the other hand, the evidence of hammer-blows to some of the gladiator's heads at Ephesus would seem to confirm the literary evidence that a mortally wounded fighter

\footnotetext{
${ }^{21}$ Junkelmann 2000, 124-27.

${ }^{22}$ Junkelmann 2000, 24-26; Pliny Ep. 31 refers to criminals at Nicomedia and Nicaea among other places in Bithynia who had been sentenced this way but who had managed to have themselves made public slaves - in some cases with an annual salary.

${ }^{23}$ Junkelmann 2000, 134-35.

${ }^{24}$ E.g., Mart, Spect. 31.5 .

${ }^{25}$ Juv. 3.34-37; Prud. Clem. contra Symm. 2.1096.
} 
might be put to death by this method. ${ }^{26}$ That aside, it is clear that from the early to middle Imperial periods, there was an overall increase in fights to the death between professional gladiators. $^{27}$

\section{THE EVIDENCE FROM ANCYRA}

1) The oft-cited 'Imperial Priest List' inscribed during the early $1^{\text {st }}$ century AD on the pronaos of the so-called Temple of Rome and Augustus at Ancyra provides us with some of the earliest evidence for the popularity of such shows in Asia Minor. ${ }^{28}$ The relevant parts read:

a) In $\mathrm{AD} 20 / 21$, (?)Castor, son of king Brigatus, provided - inter alia 'gladiatorial spectacles ${ }^{29}$ with 30 pairs of gladiators, bull-hunts, and wildbeast hunts'.

b) In $\mathrm{AD} 21 / 22$, Rufus organised '(gladiatorial) shows (and) a hunt'.

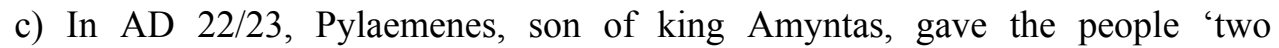
gladiatorial spectacles ... bull fighting, (and) a hunt'.

d) In AD 24/25, Amyntas supervised '(gladiatorial) shows'.

e) In AD 30/31, Pylaemenes, son of king Amyntas, again organised a festival that included 'gladiatorial spectacles ... bull fighting; bull wrestling; 50 pairs of gladiators ... (and a) wild-beast fight'.

f) In AD 31/32, (?)M. Lollius gave a display of '25 pairs of gladiators (at Ancyra) and 10 pairs at Pessinus'.

g) After a gap of at least seven years, Pylaemenes, son of Menas, provided '30 pairs of gladiators'.

h) His successor, (?)Iulius Aquila, organised '(gladiatorial) shows'.

In all, then, between the years AD 20/21 and c. 40-45, the High Priests of Ancyra organised and paid for no less than eight gladiatorial shows as part of their annual festivities, using at least 135 pairs of gladiators. Unfortunately, no details are provided of the types of gladiators used: however, a gladiatorial show at Mylassa in about $50 \mathrm{BC}$ included a fight between a murmillo and a thraex, ${ }^{30}$ revealing that these classes of gladiator were available in Anatolia in the Republican period. Indeed, as we will see, these were in fact the most popular pairings by far in the Greek-speaking East.

\footnotetext{
${ }^{26}$ Cf. Kanz and Großschmidt 2006, with Tert. Apol. 15.4.

${ }^{27}$ Ville 1981, 318-25.

${ }^{28}$ For the text, cf. Bosch 1967, 35-49, no. 51; the most conveniently available discussion of this document remains that of Mitchell 1993, 100-117, with a translation on p. 108, on which the following is based. For other places with gladiatorial events in the $1^{\text {st }}$ century AD, cf. Robert 1940, 264-65.

${ }^{29}$ The usual Greek term for describing gladiatorial spectacles was $\mu о v o \mu \alpha ́ \alpha \omega \varsigma$ (as here), meaning 'single-combat', but the term $\theta \dot{\varepsilon} \alpha \varsigma$ for 'shows' was also used (as in other entries).

${ }^{30}$ Cic. Phil. 6.13.
} 
The gladiatorial shows recorded on the 'Imperial Priest List' belong to a period long before the earliest of the seven or eight monuments cited in the literature that indicate gladiatorial games at Ancyra. On account of their stylistic and epigraphic features, these monuments can all be broadly dated to between the early/mid- $2^{\text {nd }}$ and early $3^{\text {rd }}$ century and that being so, it will be perhaps best to describe them in their original order of discovery and/or publication.

2) The $1.5 \mathrm{~m}$. high funerary monument to the 57 years-old summarudis Publius Aelius from Pergamum, carved in the form of a funerary bomos (Fig. 1) can be dated to the mid or later $2^{\text {nd }}$ century as his name shows that either he or one of his forebears received citizenship under Hadrian. ${ }^{31}$ Dedicated by his wife Aelia, she taking her husband's name as her own in accordance with Roman custom, the text records that Aelius was a member of the college of summarudes at Rome itself, and also an honorary citizen of Thessalonica, Nicomedia, Larisa (either Larisa, Greece, or Larisa in the Troad), Philippopolis, Apros, Berge (sic, for Perge), Thasos, Bizye and Abdera. As we have seen, a summarudis was the senior ranking of the two referees in a gladiatorial contest, and this text provided the first evidence that the summarudes were officially organised as a collegia. That aside, Aelius' honorary citizenship of no less than nine places in the Eastern Empire should represent communities where he served honourably as a summarudis. Of greater interest is that the badly abraded relief shows Aelius in the usual costume worn by a summarudis, his striped tunic tied at the waist and his striped mantle of office over his shoulders. ${ }^{32}$ His left hand is wrapped in the mantle and his right hand holds an object that has usually been interpreted as the rudis symbolising his office, although autopsy and the width of the damaged area suggests he was holding both a rod and a palm branch.

3) The $50 \mathrm{~cm}$. high funerary plaque of the murmillo Peitheros is the sole Ancyran gladiator's monument with a secure provenance, having been found in 1927 in the huge Roman cemetery complex that once existed near the Railway Station (Fig. 2). ${ }^{33}$ The text provides the barest of facts: his name, Peitheros; his place of origin, Oescus (modern Gigen, Bulgaria); and the name of the monument's dedicator, Messenia. The lack of any indication as to Messenia's relationship to Peitheros suggests that she was a slave concubine, and so Peitheros probably held the same status, slaves being forbidden legal marriage. The rather spirited relief shows Peitheros advancing to the left and depicts him as a short stocky man: while this was doubtless an established 'artistic conceit' for such tombstones - the shorter the relief, the cheaper the price! - the evidence from Ephesus indicates that gladiators were indeed generally broad, stocky and flat-footed men, their

\footnotetext{
${ }^{31}$ Robert 1940, 138-39, no. $90=$ Bosch 1967, 188-91, no. $149=$ French 2003, 180-81, no. 69. This relief and its inscription are very abraded and no attempt has been made to reproduce or restore the full text on this in Fig. 1: for such information the relevant bibliographical references should be consulted.

32 The costumes of the secunda- and summarudes are excellently depicted on two mosaics from Rome, revealing their mantles and tunics to be striped in blue: cf. Junkelmann, Abb. 215-216.

${ }^{33}$ Jerphanion 1928, 225-27 (the cemetery), and 269-70, no. 44 (this stone) = Robert 1940, 137, no. 88 (with ibid 1949, Pl. VIII. 2) = Bosch 1967, 192-93, no. 151 (where Peitheros is wrongly described as a secutor on the basis of the crest alone and ignoring the clear indications of a pierced visor) $=$ French 2003, 182, no. 70.
} 
heavy musculature covered with plenty of fat from a lentil and barley rich diet to better absorb flesh wounds. ${ }^{34}$ Peitheros is armed in typical murmillo fashion, wearing a heavy crested helmet, with network-pierced visor and flange, and carrying a gladius in his right hand and a broad heavy shield with his left. In addition, he wears the usual short greave on left leg, and also fasciae on his right leg as well as on his right arm. Included in the relief are a palm-branch and two crowns, ${ }^{35}$ signifying that he had won at least two victories before his death.

4) The $66 \mathrm{~cm}$. high funerary plaque of the retiarius Calleidromos, who came from the province of Asia, showed him advancing to the right (Fig. 3) ${ }^{36}$ He wears ankle-braces and a short tunic, tied at the waist by a belt with a large buckle. He is armed with a dagger in his right hand, and carries an upright trident in his outstretched left arm, his net apparently being thrown back over his right shoulder. The relief includes a dog standing by his legs, and six crowns behind him and a seventh in front, these representing his total of seven victories. ${ }^{37}$ The text begins by boasting of his courage in the $\sigma \tau \alpha \delta i o l \varsigma$, the reference in the plural meaning "many stadia', ${ }^{38}$ and goes on with the brag that he was first palus among the retiarii, the first palus being the senior of his class in a gladiatorial school. It then goes on to laconically note that in his eighth fight he met his death through the doings of the Moirai, the inescapable 'Fates', and ends with the equally curt statement that none of the dead can escape their decisions. ${ }^{39}$ As the relief lacks a dedicator, this could mean that Calleidromos was part of a familia of gladiators, the monument being erected after his death by his fellow retiarii to honour his earlier successes.

5) A statue base dedicated to an ignotus who served four-times as the agoranomos of Ancyra was erected by the eighth tribe of Ancyra in honour of his services to his fellow-citizens. ${ }^{40}$ These included inter alia 'gladiatorial shows, animal fights, and shows' over a period of 51 days.

6) An undecorated funerary monument for a thraex named Danaos was erected in his memory by his wife Tycharion ${ }^{41}$. The text describes him as being of the 'first category', that is, he was first palus in his gladiatorial familia, and gives his origin as Anazarbus in Cilicia.

\footnotetext{
${ }^{34}$ Their barley-rich diet resulted in a popular nickname for gladiators: hordearii, meaning 'barley eaters' (Pliny $H N$ 18.72). Indeed, unlike the stereotypes provided by Kirk Douglas in Spartacus and by Russell Crowe in Gladiator, these men were physically more akin to the hapless pseudo-murmillo in the film Life of Brian (1979), who dies of a heart attack while pursuing a Jewish criminal initially armed as a retiarius.

${ }^{35}$ Not one crown, as reported in French 2003, 182.

${ }^{36}$ Robert 1940, 138, no. $89=$ Bosch 1967, 191-92, no. 150.

${ }^{37}$ Jerphanion 1928, 270-272, no. 445 = Robert 1940, no. 89 (= ibid 1948, 93 , with Pl. X.1) = Bosch 1967, 191-92, no. 150. From the evidence surveyed by Ville 1981, 318-25, few gladiators in the later Imperial period survived their third combat: Calleidromos was indeed chancing the judgement of the Moriai with an eighth combat.

${ }^{38}$ Cf. Welch 1998b, 127-28.

${ }^{39}$ After all, even Zeus chose not to protect Sarpedon and Hector from the machinations of the Moirai: Il. 16.435-58 and 22.174-76.

${ }^{40}$ Robert 1940, 137, no. 87 - Bosch 1967, 117-118, no. 101.

${ }^{41}$ Robert 1950, 40, no. 328.
} 
7) A fragmented and much abraded $96 \mathrm{~cm}$. high relief panel (Fig, 4), perhaps from a funerary plaque or less likely a relief celebrating a specific munus, has a scene from a venatio with a dead lion and bear and a bestiarius(?) in the upper register, and four gladiators in combat in the lower. ${ }^{42}$ The pair on the left are both gladiators of the "heavy class', as is shown by their large oblong shields. The left-hand gladiator wears a closed round helmet with a wide flange that extends over his shoulders, and carries a shield in his left hand and a short gladius in his right, his right arm being protected by fasciae and his left leg by a greave tied behind his leg with bands. The lack of a crest on this man's helmet suggests he is a provocator, a variant of the more usual murmillo and thraex type of gladiator. ${ }^{43}$ These men also wore a pectoral to protect their chest, although on the relief the shield covers this part of the man's body. Even so, his identification as a provocator is assured by the two folds of cloth that dangle between his legs, as this class of gladiator wore a short tunic sometimes tied with a band that hung down to the knees. ${ }^{44}$ His opponent, on the other hand, is clearly a thraex, his helmet-crest terminating in a protome, and his right hand holding a sica resting against the edge of his adversary's shield, with both of his legs being protected with greaves tied at the back with bands. The left-hand of the second pair of gladiators on the right side of the relief is a secutor, readily identifiable from the long high crest that runs over his egg-shaped helmet. He wears the usual greave on his left leg, tied with bands at the back, and his right arm, with a gladius in his hand, seems to be protected by fasciae. Only the right arm and hand of his opponent now survive, the relief having broken and being very abraded at this point, but it seems that as might be expected - this gladiator was a retiarius, his trident carried in his right hand along with the short dagger that retiarii used for giving the coup de grace to their defeated rivals.

8) Another badly damaged funerary monument that may record a gladiator refers to a man whose name was missing from the surviving text, and who achieved at least three victories during his career as either an athlete or as a gladiator. ${ }^{45}$ Although the surviving parts of the recorded text clearly leave some room for both restoration and interpretation, it does imply that he died 'away from (i.e., out of) the stadias', terminology that is perhaps suited more for a gladiator than for an athlete.

\section{AMPHITHEATRE, THEATRE OR STADIUM?}

Gladiatorial contests were clearly held in Ancyra on a probably regular basis from at least the Tiberian period until the early $3^{\text {rd }}$ century, but nothing in the available epigraphic texts hints at where these contests may have taken place. It seems certain that an amphitheatre did not exist here, as none of the early travellers to Ancyra report any

\footnotetext{
${ }^{42}$ Robert 1950, 41-42, no. 329.

${ }^{43}$ Junkelmann 2000, 114-116.

${ }^{44}$ Cf. Junkelmann 2000, Abb. 173, a relief from Dyrrhachium (Durres).

${ }^{45}$ Bosch 1967, 193-94, no. 152.
} 
physical remains that might belong to such a building. ${ }^{46}$ Alternatively, the theatre at Ancyra could have been used for such shows, but there is as yet no evidence to indicate it even existed at the time when the first gladiatorial shows were held at Ancyra, although its near-circular orchestra implies that the masonry structure now visible may have replaced an earlier 'Hellenic' type theatre. ${ }^{47}$ More to the point, nothing visible at the site suggests it was provided with the necessary high wall around the orchestra to facilitate its use for gladiatorial events, nor is anything that might relate to such a construction mentioned in the admittedly limited report available for this edifice. ${ }^{48}$ In any case, the orchestra seems far too small for the extensive manoeuvring that characterised a gladiatorial fight.

As it is, Roman literature provides an initial clue as to where the earliest gladiatorial contests at Ancyra may have taken place. Thus we learn from a variety of sources how until 50 BC, when C. Scribonius Curio built the first temporary amphitheatre at Rome, ${ }^{49}$ such contests took place in any suitable and available open area: the Forum Boarium, for example, was where the first show of this type was held in 264 BC, although later in the Republican period the Roman Forum and then the Circus Maximus became the favoured locations for munera ${ }^{50}$ It is quite likely that the earliest gladiatorial games at Ancyra were likewise held in an open area within the polis, and if so, presumably its agora. ${ }^{51}$ Alternatively, they may have been held at any location outside of the coreurbanised area that could be enclosed and provided with seating on a temporary basis for this purpose. Such was in fact apparently done at Antioch in Pisidia, where a temporary wooden amphitheatre stood for two months for a munus held there in the later $1^{\text {st }}$ century AD. ${ }^{52}$ Indeed, it may well have been that these events at Ancyra took place in temporary structures at the locality named as 'Campus' in late Roman sources, and which could well have occupied the land for a hippodromos that Pylaemenes donated to his fellow-citizens at Ancyra in $\mathrm{AD} 22 / 23$. To be sure, the 'Campus' was where at least one Christian martyr met his end, ${ }^{53}$ and places set aside for gladiatorial games and the like were frequently chosen for the execution of Christians and other recalcitrants.

In fact recent research has shown that a group of andesite stones currently displayed in the Roman Baths Museum at Ankara almost certainly originated from a purpose-built stadium or hippodromos, a place that could just possibly (perhaps) be

\footnotetext{
${ }^{46}$ The much-pillaged amphitheatres at Anazabarus, Pergamum and Cyzicus show that all traces of such a structure would be almost impossible to obliterate completely - at least before relatively modern times. But note that there is no record of any traces of the amphitheatre reported to have existed at Iconium in the $4^{\text {th }}$ century: Amm. Marc. 14.2.1.

${ }^{47}$ Cf. Bennett 2006, 208-09 with Fig. 3.

${ }^{48}$ Bayburtluoğlu 1987: note, however, a reference there to the possibility that aquatic displays may have been held in this theatre. For aquatic displays in the Roman World in general, including those in theatres, see now Berlan-Bajard 2006, esp. 225-43.

${ }^{49}$ Pliny HN 36.117-120; Golvin 1990, 56-7.

${ }^{50}$ Cf., Suet. Aug. 43.1.

${ }^{51}$ For the probable location of Ancyra's agora, cf. Bennett 2006, 205 with Fig. 1.

${ }^{52}$ Cf. Mitchell and Waelkens 1988, 224-25.

${ }^{53}$ Cf. Mitchell 1982, 104-105.
} 
described as a campus. Although these stones are effectively unprovenanced, in the sense that there is no secure record of their find-spot, it has been judiciously argued from the few reports concerning their origin that this stadium may well have been located immediately south of the Roman Baths. ${ }^{54}$ More to the point, the use of stadia for gladiatorial events is well-attested in Asia Minor, their curved sphendonai being admirably suited for the building of a temporary structure to one side to form the necessary elliptical or circular arena. ${ }^{55}$ Moreover, as we have seen, the text of one of the gladiators' monuments at Ancyra does indeed refer to a stadium there. To which we might just add that double-ended stadia, such as that at Laodiceia, and evidently designed this way for such a purpose, were an architectural conceit first introduced (or so it would seem) in the Augustan period at Nicopolis in Greece, this structure being built soon after the 'Actian Games' were initiated there to celebrate Augustus' victory over Mark Antony and Cleopatra at the Battle of Actium.

Now Ancyra was, of course, an Augustan creation, and had its own version of these 'Actian Games', the Megala Augusteia Actia, although when this festival was established at Ancyra is the subject of debate. ${ }^{56}$ Even so, it is naturally tempting to associate the place that Pylaemenes provided in $\mathrm{AD} 22 / 23$ for the hippodromos with both the 'Campus' and this putative stadium, and to go further and speculate that this was where the Megala Augusteia Actia and other such festivals, including gladiatorial shows, took place. Whether or not it was a double-ended structure of the type inspired by the stadium at Nicopolis is, of course, impossible to decide from the surviving evidence. It could have been the case that when necessary, the sphendone of a normal U-shaped stadium was converted into a temporary timber-built elliptical structure for gladiatorial events, and that over time, as these increased in popularity to the exclusion of traditional Hellenic sporting contests, the sphendone was converted to become a stone-built structure of amphitheatrical form, as at Ephesus and several other stadia in Anatolia. ${ }^{57}$

\section{DISCUSSION}

Over 56 poleis in the Anatolian provinces have provided evidence for gladiatorial shows, 32 of them in Asia alone, and the figured and epigraphic evidence suggests that most contests revolved around either a thraex and/or a murmillo, although retiarii are also well-represented in the region. ${ }^{58}$ In most cases these shows were, as at Ancyra, presented by the High Priest of the Imperial cult, although other high-ranking officials, such as Asiarchs and Lysiarchs, also promoted them. Indeed, while civic magistrates sometimes

\footnotetext{
${ }^{54}$ Görkay 2006; cf. Bennett 2006, 213, for the alternative location of the campus in the U-shaped valley between the Temple to Augustus and Roma and the theatre.

${ }^{55}$ Welch 1998b, 127-28: the double-ended stadia at Laodicea (the $\sigma \tau \alpha \dot{\alpha} \delta \imath v \dot{\alpha} v \varphi \imath \theta \varepsilon \dot{\varepsilon} \alpha \rho o v$ ) and Aphrodisias both date - in their built-form - to the Flavian period.

${ }^{56}$ Bennett 2006, 201-202.

${ }^{57}$ Cf. Welch 1998b, 122, n. 9, citing other examples at Aphrodisias, Perge, Ephesus, Aspendos, Laodiceia and the Panathenaic Stadium in Athens.

${ }^{58}$ Magie 1950, 655, following the information provided in Robert 1940, 1946 and 1947.
} 
paid for gladiatorial spectacles, ${ }^{59}$ it seems that they were primarily connected with celebrations of the Imperial Cult. Moreover, it may well have been the case that each provincial capital had its own familia of gladiators and venatores for such purposes. ${ }^{60}$ There is as yet no direct evidence that such a familia existed at Ancyra, ${ }^{61}$ but it does seem probable that one did exist. Such is inferred from an inscription of early $3^{\text {rd }}$ century date from Ancyra dedicated to M. Didius Marimus as Imperial procurator of Galatia and protem procurator of Arabia, and which records among his earlier official posts service as procurator of the gladiator schools (fam(iliae) glad(iatoriarum)) of Asia, Bithynia, Galatia, Cappadocia, Lycia, Pamphylia, Cilicia, Cyprus, Pontus and Paphlagonia. ${ }^{62}$ It seems quite reasonable to assume that these gladiatorial schools were centred on their respective provincial or regional capitals, in which case the Galatia school would be based at Ancyra.

\footnotetext{
${ }^{59}$ Philos. Vit. Apoll. 4.22.

${ }^{60}$ Robert 1940, 240 and 267-75; cf. Mitchell 1997, 110-11.

${ }^{61}$ But note no. 4 above, a relief possibly erected by members of a familia.

${ }^{62}$ Bosch 1967, 336-340, no. 276.
} 


\section{BIBLIOGRAPHY}

Bayburtluoğlu, İ., 1987, ‘Ankara Antik Tiyatrosu’, Anadolu Medeniyetleri Müzesi - 1986 Yıllığı (1987), 39-43.

Bennett, J., 2001, Trajan, Optimus Princeps (Routledge).

Bennett, J., 2006, 'The Political and Physical Topography of Early Imperial Graeco-Roman Ancyra', Anatolica 32, 189-27.

Berlan-Bajard, A., 2006, Les Spectacles Aquatiques romains (Rome).

Bosch, E., 1967, Quellen zur Geschichte der Stadt Ankara in Altertum (Ankara).

Rustafjaell, R. de, 1902, 'Cyzicus', JHS 22 (1902), 174-89.

French, D.H. 2003: Inscriptions of Ankara (Ankara).

Görkay, K., 2006, ‘Ankara’s Unknown Stadium', Ist. Mitt. 56 (2006), 247-71.

Golvin, J.-C., 1988, L’amphithéatre romain (Paris).

Gough, M., 1952, ‘Anazarbus', Anat. Stud. 2 (1952), 84-150.

Hasluck, F.W., and Henderson, A.E., 1904, 'On the Topography of Cyzicus', JHS 24 (1904), 135-43.

Jerphanion, G. de, 1928, Mélanges d'Archéologie Anatolienne (= Mélanges de l'Université Saint-Joseph Beyrouth 13/1: Beirut).

Junkelmann, M., 2000, Das Spiel mit dem Tod: so kämpften Roms gladiatoren (Mainz).

Kanz, F. and Großschmidt, K., 2002, 'Waffenwirkung und Verletzungsspuren. Der Traumatologische Befund', in Krinzinger 2002, 43-48.

Kanz, F. and Großschmidt, K., 2005, 'Stand der anthropologischen Forschungen zum Gladiatorenfriedhof in Ephesos’, ÖJh 74 (2005), 103-23.

Kanz, F. and Großschmidt, K., 2006, 'Head Injuries of Roman Gladiators', Forensic Science International 160: 2/3 (2006), 207-16.

Krinzinger, F. (ed.), 2002, Gladiatoren in Ephesos. Tod am Nachmittag, Eine Ausstellung im Ephesos Museum Selçuk (Istanbul/Vienna).

Magie, D., 1950, Roman Rule in Asia Minor (Princeton NJ).

Mitchell, S.M., 1982, 'The Life of Saint Theodotus of Ancyra', Anat. Stud. 32 (1982), 93-114.

Mitchell, S.M., 1993, Anatolia: Land Men and Gods 1: The Celts and the Impact of Roman Rule (Oxford).

Mitchell, S., and Waelkens, M., 1998, Pisidian Antioch: the site and its monuments (London).

Radt, W., 1999, Pergamon. Geschichte und Bauten einer antiken Metropole (Darmstadt).

Reynolds, J., 1991, 'Epigraphic evidence for the construction of the theatre', in Smith, R.R.R., and Erim, K.T. (edd.), Aphrodisias papers 2 (Ann Arbor MI), 15-28.

Robert, L., 1940, Les Gladiateurs dans l'Orient Grec (Paris).

Robert, L., 1946, 'Monuments de Gladiateurs dans l'Orient grec', Hellenica 3, 112-150.

Robert, L., 1948, 'Monuments de Gladiateurs dans l'Orient grec', Hellenica 5, 77-99.

Robert, L., 1949, 'Monuments de Gladiateurs dans l'Orient grec', Hellenica 7, 126-151.

Robert, L., 1950, 'Monuments de Gladiateurs dans l'Orient grec', Hellenica 8, 39-72.

Stillwell, R., Corinth II: the theatre (Princeton).

Ville, G., 1981, La gladiature en occident des origines à la mort de Domitien (Rome).

Welch, K., 1998a, 'The Stadium at Aphrodisias', AJA 102/3 (1998), 547-69.

Welch, K., 1998b, 'Greek Stadia and Roman Spectacles: Asia, Athens, and the tomb of Herodes Atticus', JRA 11, 116-45. 

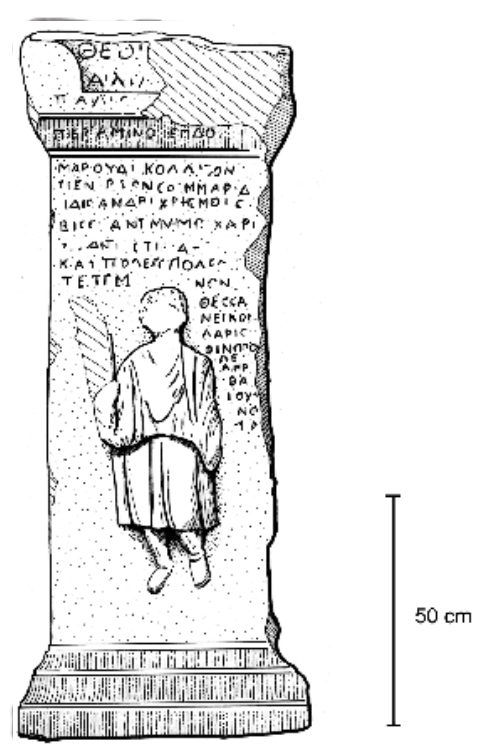

Fig. 1. The summarudis Publius Aelius: drawing by B. Claasz Coockson after French 2003, 180-81, no. 69.

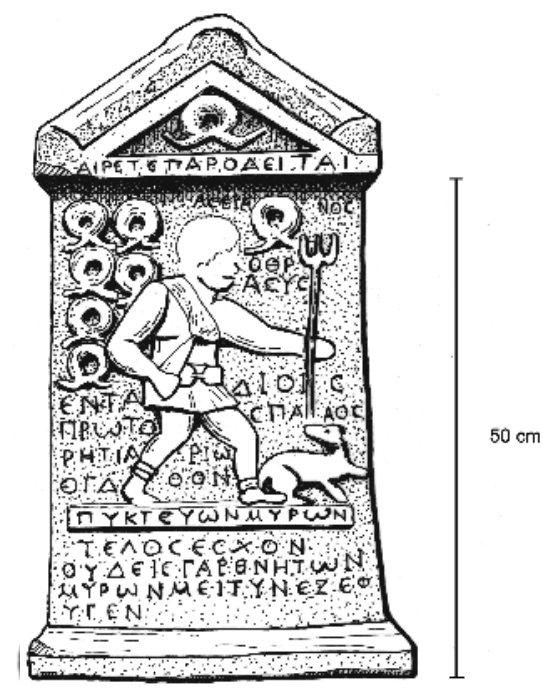

Fig. 3. The retiarius Calleidromos: drawing by B. Claasz Coockson after Jerphanion 1928, 270-272, no. 445 and Robert 1948, Pl. X.1.

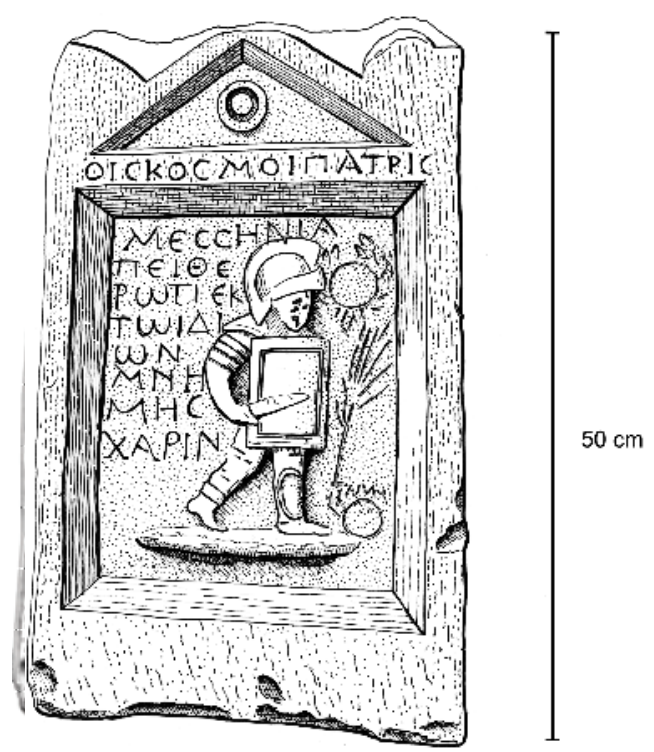

Fig. 2. The murmillo Peitheros: drawing by B. Claasz Coockson after Robert 1949, PI. VIII. 2.

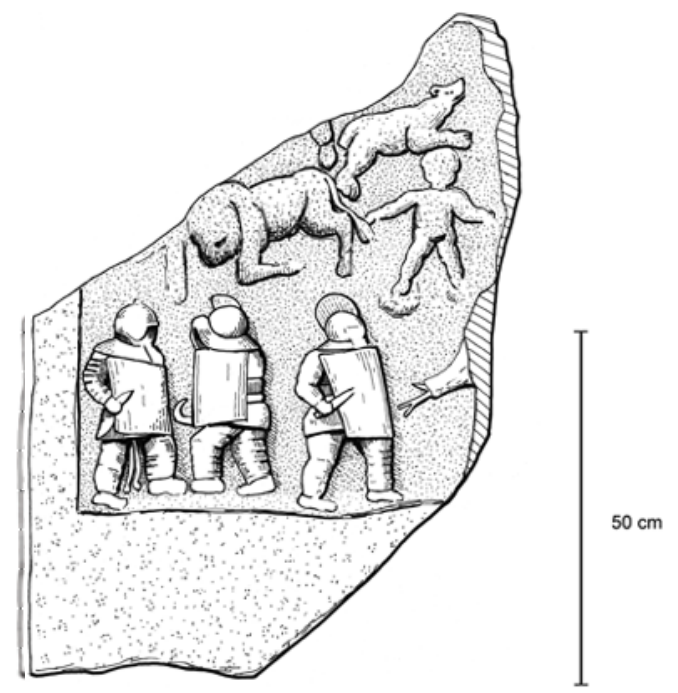

Fig. 4. The munus relief: drawing by B. Claasz Coockson after Robert 1950, 41-42, no. 329. 